\title{
Customer Retention of Mobile Phone Purchasing on Cell Phone Stores in Denpasar
}

\author{
Anak Agung Ngurah Gede SADIARTHA ${ }^{1}$
}

\begin{abstract}
This paper aims to identify customer retention on mobile phone purchasing on cell phone stores in Denpasar. This study used a quota sampling method to get 240 respondents. Service quality was measured using the Structural Equation Modeling (SEM)) model. The formulation of the problem is as follows: "What is the function of customer retention of cellular phone purchases at cellular phone shops in Denpasar City." The purpose of this study was to analysis customer retention of mobile phone purchasing on cell phone stores in Denpasar. Data were collected through survey research, and 240 cell phone owners. The outcome showed that service quality has a negative but significant effect on customer retention, service quality has a positive but not significant effect on promotion at cell phone stores, trademark have a positive and significant effect on customer retention at cell phone stores, trademarks have a positive and significant effect on promotions at cell phone stores, promotions positive and significant effect on customer retention in cell phone stores. Thus, the results showed that trademarks and promotions make cell phone store managers can carry out effective customer retention to develop their business.
\end{abstract}

KEYWORDS: customer retention, promotion, service quality, trademark.

JEL CLASSIFICATION: $M 19, M 21, M 30, M 31$

\section{INTRODUCTION}

The need for information cannot be separated from sophisticated access to media facilities in banking technology. The presence of new media can provide unlimited information without the limit of cultural and social influence in a country which is formed in a network by using a computer called handphone. In Indonesia, a developing country, the need for information is very high whether for the personal, organization, and social life. One of the best ways to collect this information is by using a mobile phone. Using a mobile phone, anyone will be able to access information from anywhere in the world. The development of handphones forms a new side of the world which is commonly called a virtual world. Every person has the right to deal with other individuals without any limitations. Globalization has been carried out in the virtual world which has connected all digital communities or those who often use mobile phones in their daily life activities. With 250 million populations of people, Indonesia is a potential market and becomes the largest market in Southeast Asia in terms of mobile phone usage (Krisnadewara, 2004). It is led to the emergence of new businesses in hand phone usage and finally, new entrepreneurs in developing cell phone stores. The development of cell phone stores in Indonesia is not a new thing in the business world since business in that place can provide huge benefits for entrepreneurs. The business management of the cell phone store is inseparable from the aspects of marketing, technical operation, finance, human

\footnotetext{
${ }^{1}$ University Hindu Indonesia, Denpasar, sadiartha.unhi@gmail.com
} 
resources, and management. Cell phone store is also inseparable with trademark since trademark aims to maintain the survival business since the existing products are sensitive with changing needs and tastes of consumers, technology, shorter product life cycles, and the increasing amount of competitors. Changes in cell phone store business environment have forced managers to be able to create new thoughts, ideas, and innovation in the form of computer technology, design, the layout of a comfortable playroom, online gaming facilities, etc. Thus, trademarks have importance not only as a tool to maintain the viability of companies but also to win in a competition. The cell phone store market is very broad and the competition is very fierce. Every entrepreneur or manager of cell phone stores must be able to win the market by creating new trademarks and providing brilliant ideas for the sake of their business. Trade can also be used as one of the strategies to achieve a competitive advantage. For cell phone store managers, success in trademarking means one step ahead of their competitors. Competition among sellers in getting customers cannot be separated from service quality. Service quality acts as a medium where managers or companies can inform, persuade, and remind consumers directly or indirectly about the products or services provided (Kotler and Keller, 2011). The quality of services performed by cellular store managers will raise a judgment on customers, so it will directly or indirectly create an image of the cellular store services. The current business paradigm requires businessmen to find valuable market scope and provide further opportunities for strategies to develop and gain a competitive advantage. The key to the success of a cell phone store business lies in the strategy which later will be formulated and implemented. This strategy should be synergistic with promotion to surpass the superior competition and achieve company goals. Promotion includes dimensions of durability, imitability, and easiness to match assets strategy owned by businesses man (Ferdinand, 2002). Widespread promotion reaches almost all fields of business, both businessoriented businesses and non-business ventures. This is due to expect results for consumers to reach the target. The company tries to hold promotions with consumers so they can persuade and influence it to follow the company's wishes. (Unonongo, et al, 2015).

A competitive advantage occurs if the operational costs of business activities are lower than competitors. In the end, promotion is the easiest strategy for businessman especially in the field of cell phone stores to act as a reliable and capable market player. The expansion of cell phone stores in Denpasar has not changed yet. The business connections and hand phone networks have not satisfied customers yet. Moreover, some aspects of activities regarding trademark in making something new in cell phone stores and quality of services is not run well. Cell phone store growth is increasing because this business offers a great opportunity to gain large profits. However, the cell phone store business is inseparable from bankruptcy. In the table above, many collapsed stores in Denpasar experienced huge losses. If this incident continues, it will gain a negative effect on other survival. Therefore, this business must be well-coordinated and planned by owners so that the entire store activities can lead to goals set by the business owner. Based on these problems, it can be formulated that this study will examine how customer retention of cellular phone purchases at cellular phone shops in the city of Denpasar. With this background, the authors formulate the problem as follows: "How does the customer retention function of cell phone purchases at cellular phone shops in the city of Denpasar." The purpose of this study was to analysis customer retention of mobile phone purchasing on cell phone stores in Denpasar.

\section{CONCEPTUAL FRAMEWORK}

\subsection{Trademark}

Trademark is a name or symbol associated with products or services and rise psychological meaning; trademark is also industrial assets including intellectual property conventionally. Trademark is used on goods traded by a person or several people or legal entities to 
differentiate from other similar goods. Sutjipto (1984) states that the trademark is a sign to personalize a certain object so it can be distinguished from other similar objects. According to Kotler and Lane (2011), trademark indicators are memorable, meaningful, likable, changeable, adaptable, and protectable.

\subsection{Service quality}

Lewis and Booms are experts who first revealed the definition of service quality which is a measure of how well the level of service provided is capable and connected with customer expectations (Tjiptono \& Chandra, 2007). Service quality can be realized between the meeting of costumers' needs, costumers' desires, and the accuracy of message delivery to fulfill customer expectations. Service quality has two main factors namely the expected service and perceived service. Based on Wolkins (Tjiptono \& Chandra, 2007), Service Quality has six factors as follows: Leadership, Education, Strategic Planning, Review, and Communication. According to Zeithaml and Berry (Tjiptono \& Chandra, 2007), the dimensions of service quality are divided into five dimensions, those are: Reliability, Responsiveness, Guarantees, Empathy is costumers' problems management from the company through sufficient operating hours, Physical evidence

\subsection{Promotion}

Promotion of one of the factors that is needed in introducing goods or services and can provide information for consumers about goods and services produced by the company. Promotion is a form of marketing communication that includes marketing activities to disseminate information to customers or consumers, persuade and remind the company of the target market so that consumers are willing to accept, buy, and like the products offered (Tjiptono, 2002). According to Kotler and Armstrong (2012), promotion is a presentation and promotion that requires cost, goods or services, and ideas. Sales pitch is a short-term incentive to drive sales of products or services. Public relations build good relationships with various public companies through several ways to get the limelight, build a good corporate image, and clarify rumors. Direct Marketing is a direct transaction with customers to get direct feedback and build customer relationships.

\subsection{Customer Retention}

Kaplan and Norton (2000) explain customer retention is an activity to maintain an ongoing interaction relationship with customers and with ongoing relationships that marketing loyalty, database marketing, marketing permits, and progress can be gained. Furthermore, Kaplan and Norton (2000), customer value of past events and current customer behavior are the best predictors of future customer behaviour. Active customers then have to be maintained as the main customer and they like you "Win". Therefore, paying attention to the customer's durability is a way to control customer characteristics such as sending birthday greetings and other possible forms of attention. Customer retention is an action-reaction-feedback-repeat. As a result, customer retention can be done in terms of action actions, and then get a reaction. Afterwards, there is feedback from the actions taken by the customer and vice versa, customer retention requires allocating marketing resources. Companies must conduct some marketing activities to retain customers who automatically generate higher returns and more. Customer retention is done in the company's effort to meet the various needs of customers. The size of retaining customers can provide feedback on how well the company manages the business. The economic benefits of retaining customers are declining costs of new customer acquisition; Increased basic gains; Increase repetitive revenue growth; Positive impacts on corporate profits; Cost savings; Referrals where old customers will indirectly recommend new customers through the mouth; and a premium price where customers feel satisfied although 
the price is a bit higher because the service provided is very good. The dimensions to retain customers according to DeSouza (Tjiptono and Chandra, 2007) are as follows. Competitive prices with others, delivering premium products from previous ones to customers, providing better service than ever before, expanding the market to a wider area, technology, ensuring technology is available and sophisticated to facilitate consumers to use it. In this study the conceptual framework can be described as follows:

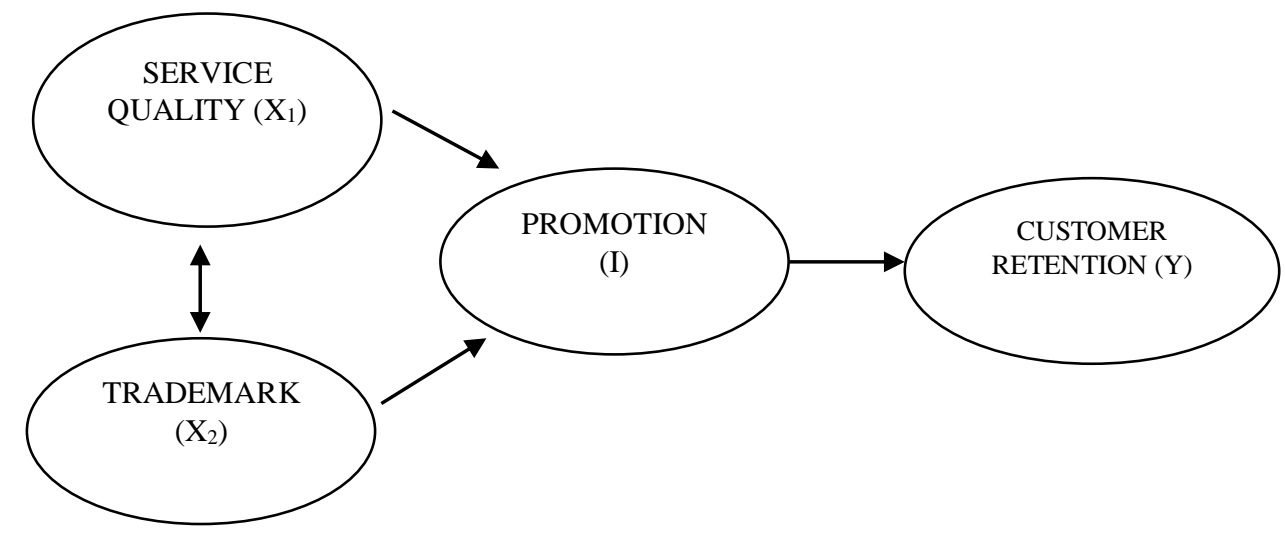

Figure 1. Conceptual framework

\section{METHODOLOGY}

\subsection{Type and nature of research}

This study was conducted using a survey method approach. This is quantitative descriptive research that aims to describe the characteristic of a situation or research object the collection and analysis of quantitative data and statistical testing (Churchill, 2005). The nature of this study is explanatorily intended to explain the position of the variables studied and the relationship between one variable with another variable (Sugiyono, 2008).

\subsection{Research sites}

This research was conducted in Denpasar consisting of 7 districts.

\subsection{Population and sample}

The populations in this study were all cell phone store owners in Denpasar in 2019, which includes 320 businesses. The technique of data collection in this study was Quota Sampling which the researcher firstly determined how many subjects to be taken in the study (Idrus, 2009). Determining the number of samples, according to Hoogland and Boomsma (Ferdinand, 2002), taking samples in SEM research is by multiplying indicators by five to ten. Meanwhile, data with high kurtosis values must have a minimum of 10 times higher sample size than the number of free parameters. Indicators in the study are 24 , so the number of samples was the Number of Samples

$$
\begin{aligned}
& =\text { Indicator x } 10 \\
& =24 \times 10 \\
& =240
\end{aligned}
$$

From the calculation above, the number of samples in this study is 240 samples.

\subsection{Data analysis method}

Thus study used causality or relationship or influence. Measuring the proposed hypothesis, the analytical technique used was SEM (Structural Equation Modeling) using AMOS 18.0 Software. 
Table 1. Goodness-of-Fit Index

\begin{tabular}{|l|l|}
\hline Goodness-of-fit index & Cut-of value \\
\hline Chi-Square & $\alpha=5 \%$ \\
\hline Significant probability & $\geq 0,05$ \\
\hline GFI & $1>$ GFI $\geq 0,90$ \\
\hline AGFI & $1>$ AGFI $\geq 0,90$ \\
\hline CMIN/DF & $\leq 2,0$ \\
\hline TLI & $1>$ TLI $\geq 0,90$ \\
\hline CFI & $1>$ CFI $\geq 0,90$ \\
\hline RMSEA & $\leq 0,08$ \\
\hline \multicolumn{2}{|l}{ Source: Ferdinand $(2002)$} \\
\end{tabular}

\section{RESULT}

The results of testing the hypothesis of this study are discussed orderly in line with the hypotheses that have been proposed

\subsection{Service quality on promotions in cell phone stores}

The Service Quality on Promotion in Cellular Stores can be seen in Table 2.

Table 2. Hypothesis testing results

\begin{tabular}{|l|l|l|l|l|l|l|l|}
\hline $\begin{array}{l}\text { Dependent } \\
\text { Variable }\end{array}$ & & $\begin{array}{l}\text { Independent } \\
\text { Variable }\end{array}$ & Estimate & S.E. & C.R. & P & Description \\
\hline Promotion & $<-$ & $\begin{array}{l}\text { Service } \\
\text { Quality }\end{array}$ & -.095 & .044 & -2.188 & .029 & Significant \\
\hline
\end{tabular}

In the table above, each path coefficient or the direction of the causal relationship and the results of testing the hypothesis shows Quality of Service $\left(\mathrm{X}_{1}\right)$ has a significant effect on Promotion $\left(\mathrm{Y}_{1}\right)$ in a positive direction. Based on the results of the study showed the quality of service has a negative but significant effect on promotion in cell phone stores.

\subsection{Trademarks on promotions in cell phone stores}

The Trademarks on Promotions in Cell Phone Stores can be seen below:

Table 3. Hypothesis testing results

\begin{tabular}{|c|c|c|c|c|c|c|}
\hline $\begin{array}{l}\text { Dependent } \\
\text { Variable }\end{array}$ & $\begin{array}{l}\text { Independent } \\
\text { Variable }\end{array}$ & Estimate & S.E. & C.R. & $\mathrm{P}$ & Description \\
\hline Promotion & Trademark & .611 & .037 & $\begin{array}{l}16.37 \\
5\end{array}$ & $\begin{array}{l}.00 \\
0\end{array}$ & Significant \\
\hline
\end{tabular}

The table shows trademark $\left(\mathrm{X}_{2}\right)$ has significant effect on Promotion (I) with a positive relationship direction. The path coefficient (S.E) which is positive 0.37 with the value of C.R. equal to 16,375 and obtained a significance probability (p) of 0,000 which is less than the significance level $(\alpha)$ determined at 0.05 . 


\subsection{Service quality on customer retention in cell phone stores}

The Service Quality does not affect Customer Retention in Cell Phone Stores can be seen in the table below:

Table 4. Hypothesis testing results

\begin{tabular}{|l|l|l|l|l|l|l|l|}
\hline $\begin{array}{l}\text { Dependent } \\
\text { Variable }\end{array}$ & & $\begin{array}{l}\text { Independen } \\
\mathrm{t} \text { Variable }\end{array}$ & $\begin{array}{l}\text { Estim } \\
\text { ate }\end{array}$ & S.E. & $\begin{array}{l}\text { C.R } \\
.\end{array}$ & $\mathrm{P}$ & Description \\
\hline $\begin{array}{l}\text { Customer } \\
\text { Retention }\end{array}$ & $<-$ & $\begin{array}{l}\text { Service } \\
\text { Quality }\end{array}$ & .092 & .069 & 1.329 & .184 & $\begin{array}{l}\text { Not } \\
\text { Significant }\end{array}$ \\
\hline
\end{tabular}

Service Quality $\left(\mathrm{X}_{1}\right)$ has no significant effect on Customer Retention (Y) with positive relationship directions. The path coefficient (S.E) which is positive at 0.69 with the value of C.R. of 1.329 and obtained a significance probability (p) of 0.184 greater than the significance level $(\alpha)$ determined at 0.05 .

\subsection{Trademarks on customer retention in cell phone stores}

Trademark $\left(\mathrm{X}_{2}\right)$ has a significant effect on Customer Retention (Y) with positive relationship directions can be seen in Table:

Table 5. Hypothesis testing results

\begin{tabular}{|c|c|c|c|c|c|c|c|}
\hline $\begin{array}{l}\text { Dependent } \\
\text { Variable }\end{array}$ & & $\begin{array}{l}\text { Independent } \\
\text { Variable }\end{array}$ & $\begin{array}{l}\text { Estim } \\
\text { ate }\end{array}$ & S.E. & C.R. & $\mathrm{P}$ & Description \\
\hline $\begin{array}{l}\text { Customer } \\
\text { Retention }\end{array}$ & $\begin{array}{l}< \\
-\end{array}$ & Trademark & .346 & .122 & 2.825 & $\begin{array}{l}.0 \\
05\end{array}$ & Significant \\
\hline
\end{tabular}

The path coefficient (S.E) which is positive is 0.122 with a value of C.R. equal to 2.825 and obtained a significance probability (p) of 0.005 smaller the significance level $(\alpha)$ determined at 0.05 .

\subsection{Promotion on customer retention of cellular stores}

The customer retention which affects Promotions in Cell Phone Stores can be seen in Table:

Table 6. Hypothesis testing results

\begin{tabular}{|l|l|l|l|l|l|l|l|}
\hline $\begin{array}{l}\text { Dependent } \\
\text { Variable }\end{array}$ & & $\begin{array}{l}\text { Independent } \\
\text { Variable }\end{array}$ & Estimate & S.E. & C.R. & P & Descriptions \\
\hline $\begin{array}{l}\text { Customer } \\
\text { Retention }\end{array}$ & $<-$ & Promotion & .430 & .183 & 2.346 & .019 & Significance \\
\hline
\end{tabular}

Promotion $(\mathrm{Z})$ has a significant effect on customer retention $(\mathrm{Y})$ with a positive relationship direction. The path coefficient (S.E) is positive with a value of 0.183 with a value of C.R. of 2.346 and obtained a significance probability (p) of 0.019 which is less than the significance level $(\alpha)$ determined at 0.05 . 


\section{CONCLUSION}

The trademark, service quality, promotion, prioritizes various ways of marketing communication and promotion with the offer between the company and the customer using the phone's mobile technology, various meanings regarding the media of the mobile phone, devices, channels, and technology, very main and important potential in the retail environment. This is because it gives an opportunity to change the paradigm on consumer retention. This research provides a conceptual framework consisting of four key entities: trademark, service quality, promotion, and customer retention. Key-related problem frameworks such as promotional activities, trademark segments, service quality, and customer retention activities and competition. Through this research the success of mobile store retailers to implement marketing strategies, identify customer-related and organizational challenges on this research, and outline future research scenarios and avenues relating to this issue.

\section{ACKNOWLEDGEMENTS}

Acknowledgments truly and profusely I give the team contribution for the completion of this paper. All efforts and cooperation so far can provide very satisfying results. I thank the following personal contributions: Dewa Ayu Suci Lestari, Ni Nyoman Sunita.

\section{REFERENCES}

Churchill, G. A. (2005). Basic Marketing Research. Fourth Edition. Indonesian Edition (Translated by Koswara, Dira Salam, and Alvin Ruzhendi). Erlangga Jakarta.

Ferdinand, A. (2002). Structural Equation Modeling in Management Research, Diponegoro Publishing Agency, Semarang.

Idrus, M. (2009). Social Science Research Methods, Qualitative and Quantitative Approaches, Second Edition, Erlangga Publisher, Jakarta.

Kaplan, S. R. \& Norton, D. P. (2000). Balanced Scorecard, Translations, Erlangga Publisher, Jakarta.

Krisnadewara, D. (2004). Survey of Mobile Phone Connection Performance and Internet Cafe Ionization Ability, Performance Journal, Volume 8, No.1, of 2004.

Kotler, P. \& Armstrong, G. (2012). Principles of Marketing. Issue 13, Volume 1. Jakarta: Erlangga.

Kotler, P. \& Keller, K. L. (2011). Marketing Management, Volume 2, Issue 13, Translation, Erlangga Publisher, Jakarta.

Sugiyono (2008). Business Research Methods, Publisher Alfabeta, Yogyakarta.

Sutjipto, Purwo, H. M. N. (1984). Understanding The Principles Of Indonesian Commercial Law, Djambatan.

Tjiptono, F. (2002). Marketing Strategy. Yogyakarta: Andi Publisher.

Tijptono, F. \& Chandra, G. (2007). Service, Quality And Satisfaction, ANDI Yogyakarta Publisher.

Unonongo, W., Warouw, D. \& Tulung, L. (2015). Promotion Function in Increasing the Purchasing Power of Samsung Gadgets in the City of Manado. Acta Full of Communication, 4(5).

Vyandra (2006). Innovative Entrepreneur, Publisher of Media Ideas, Semarang. 